\title{
AGREGATY HALITOWE \\ WSPÓLCZESNYCH ŚRÓDLĄDOWYCH ZBIORNIKÓW SŁONYCH - REMINISCENCJE Z WYPRAW NAUKOWYCH PSGS \\ Halite aggregates of the recent salt lakes - the preliminary study from PSGS excursions
}

\section{Hanna TOMASSI-MORAWIEC ${ }^{1}$, Grzegorz CZAPOWSKI ${ }^{1}$ \& Michael SCHRAMM ${ }^{2}$}

\author{
${ }^{1}$ Państwowy Instytut Geologiczny - Państwowy Instytut Badawczy; \\ ul. Rakowiecka 4, 00-975 Warszawa; \\ e-mail: hanna.tomassi-morawiec@pgi.gov.p grzegorz.czapowski@pgi.gov.p \\ ${ }^{2}$ Federalny Instytut Nauk o Ziemi i Surowców Naturalnych (BGR); Hanower, Niemcy; \\ e-mail: Michael.Schramm@bgr.de
}

Treść: W brzeżnych partiach dwóch słonych zbiorników bezodpływowych: Morza Martwego w Izraelu (wyprawa PSGS w 2006 r.) i jeziora Tuz w Turcji (wyprawa PSGS w 2011 r.) napotkano sferyczne agregaty kryształków halitu. W Morzu Martwym ,kulki” halitowe (o średnicy od kilku milimetrów do kilku centymetrów) zaobserwowano w strefie płytkiego przybrzeża z występowaniem wyraźnych prądów. W przypadku jeziora Tuz kuliste agregaty halitowe (o średnicy $0,5-0,7 \mathrm{~cm}$ ) występowały na powierzchni skorupy solnej utworzonej w wyniku odparowania wód jeziora w okresie letnim. Formy z dna Morza Martwego to zapewne pizoidy, powstałe na bazie ooidów halitowych wskutek agradacji kryształków solnych wytrąconych z nasyconej względem halitu solanki i przetaczanych po dnie przez przydenne prądy wyrównawcze i falowanie sztormowe. Genezę „,kulek” z jeziora Tuz należy prawdopodobnie wiązać z działalnością wiatru (halitowe „ooidy eoliczne”) i są one produktem transportu eolicznego agregatów i pojedynczych kryształów halitu po odsłoniętej, chropowatej powierzchni skorupy solnej. Oznaczone w kilku „kulkach” zawartości bromu są zbliżone do wartości spotykanych w halitach powstałych z morskich solanek.

Słowa kluczowe: agregaty halitowe, słone jeziora, Morze Martwe, jezioro Tuz

\begin{abstract}
In the nearshore parts of recent salt lakes - the Dead Sea (Israel) and the Tuz Lake (Turkey) - during the two PSGS excursions (2006' and 2011') spherical forms of fine-grained halite accumulation were found. These ones from the Dead Sea (few milimetres to few centimetres in diameter) were observed on the nearshore bottom with active bottom currents. The halite "balls" from Tuz lake Lake $(0.5-0.7 \mathrm{~cm}$ in diameter) were observed on the salt crust surface that forms every year in dry season. It seems that crystal aggregates from the Dead Sea are the halite pisoids, formed due to continuous concentration of halite crystals, precipitated from the halite-saturated brines, onto the former fine halite ooids. Such forms became rolled and moved on the nearshore bottom by the bottom currents and storm waving. Salt "balls" from the Tuz Lake are rather of aeolian origin (halite "aeolian ooids") and they are the product of aeolian transport of the halite aggregates and crystals on the rough surface of exposed salt crust. The bromine content determined in few "balls" is similar to that observed in halites originated from marine brines.
\end{abstract}

Key words: halite aggregates, salt lakes, Dead Sea, Tuz Lake 


\section{WSTEPP}

Podczas dwóch wypraw naukowych PSGS w brzeżnych partiach słonych zbiorników bezodpływowych (Fig. 1): Morza Martwego w Izraelu (wyprawa w 2006 r.) i jeziora Tuz w Turcji (wyprawa w 2011 r.) zaobserwowano ciekawe formy sedymentacji halitowej-kuliste i owalne agregaty kryształków halitu o średnicy od kilku milimetrów do kilku centymetrów. Podejrzewano, że mogą to być ooidy halitowe (halooidy i halopizoidy), spotykane zarówno w Morzu Martwym (Weiler et al. 1974, Melvin 1991, Schreiber \& El Tabakh 2000), jak i w jeziorze Tuz (Tekin et al. 2007), a także w innych współczesnych słonych zbiornikach naturalnych, np. na obrzeżu słonego jeziora Asal w Dżibuti we wschodniej Afryce (Castanier et al. 1992, 1999) czy salinach karaibskiej wyspy Bonaire (Melvin 1991, Warren 2006). Genezę ooidów halitowych (halooidów) thumaczy się dwojako: (1) w stężonych solankach ( $>20 \% \mathrm{NaCl}$ ) obecne są kolonie bakterii halofilnych (Halobacteriaceae), których rozwój zarówno indukuje krystalizację halitu w halooidach, jak i ma wpływ na ich teksturalną orientację (Castanier et al. 1992, 1999); (2) halooidy są wynikiem sukcesywnego obrastania przez halit jąder krystalizacji, którymi mogą być kryształy halitu i okruchy skał. Formy te są unoszone i obracane w przesyconej, wzburzonej sztormowym falowaniem solance (Weiler et al. 1974, Sonnenfeld 1984).

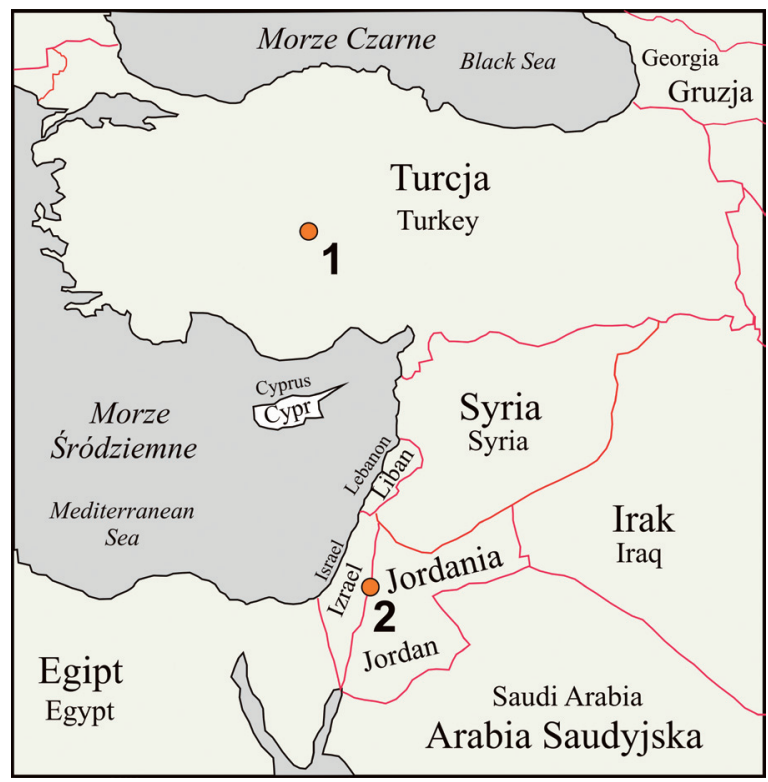

Fig. 1. Mapa lokalizacyjna opróbowanych zbiorników słonych: 1 - jezioro Tuz, 2 - Morze Martwe

Fig. 1. Location map of the sampled salt lakes: 1 - Tuz Lake, 2 - Dead Sea

Pobrane okazy tych kulistych i owalnych tworów poddano wstępnej analizie makro- i mikroskopowej (mikroskop polaryzacyjny). W kilku okazach oznaczono też zawartość bromu. 


\section{MORZE MARTWE}

Morze Martwe to gigantyczne jezioro słone (powierzchnia ok. $1020 \mathrm{~km}^{2}$, gł. >300 m) (Burliga et al. 2007), położone w depresji (ok. 418 m poniżej poziomu morza) ponad aktywną strefą przesuwczą w obrębie ryftu Morza Martwego (Zak 1967, Rosenthal et al. 2006, Weineberger et al. 2006, García-Veigas et al. 2009). Wyodrębnia się w nim dwa zbiorniki: właściwe: Morze Martwe w części północnej (Fig. 4A) o powierzchni $750 \mathrm{~km}^{2}$ i głębokości do $400 \mathrm{~m}$ oraz tzw. zatokę Sedom w części południowej, o powierzchni $250 \mathrm{~km}^{2}$ i głębokości do $6 \mathrm{~m}$ (Weiler et al. 1974). Obie części przedzielone są elewacją podłoża Lisan (Fig. 2A). Poniżej współczesnych sedymentów basen jeziora wypełniają plioceńskoplejstoceńskie osady jeziorne i fluwialne, podścielone solnymi utworami formacji Sedom (Fig. 2C) powstałej w plioceńskiej lagunie Sedom (Fig. 2B) z ewaporacji wód ówczesnego Morza Śródziemnego, zasilających zatokę na terenie ryftu (Raab et al. 2000, García-Veigas et al. 2009). Formacja ta osiąga miąższość1500-2000 m i zbudowana jest głównie z soli kamiennej, której towarzyszą podrzędnie sole potasowe, anhydryty i skały mułowcowoilaste (Zak 1967, vide: Weinberger et al. 2006, García-Veigas et al. 2009). Utwory formacji Sedom są przykryte formacjami węglanowymi i klastycznymi o zróżnicowanej miąższości: od $1700 \mathrm{~m}$ na obrzeżach basenu do $5500 \mathrm{~m} \mathrm{w}$ jego części centralnej (Weinberger et al. 2006). Aktywność uskoków podłoża otoczenia i depresji, głównie obramowujących ją od wschodu i zachodu, oraz podrzędnych uskoków poprzecznych w części południowej (Fig. 2A) doprowadziła do mobilizacji formacji solnej i rozwoju struktur diapirowych: wysadów Sedom i Lisan (Weinberger et al. 2006). Najlepiej poznanym i udokumentowanym pod względem geologicznym i geofizycznym wysadem solnym w tym rejonie jest wysad Sedom, znajdujący się w południowo-zachodniej części Morza Martwego ponad uskokiem Sedom (Fig. 2C). Otoczenie basenu Morza Martwego i jego głębokie podłoże budują utwory węglanowe kredowej Judea Group (Fig. 2C) (Zak 1967, Rosenthal et al. 2006, Weineberger et al. 2006).

Zbiornik Morza Martwego wypełniają głównie solanki typu $\mathrm{Ca}-\mathrm{Cl}$ o zawartości od $290 \mathrm{~g} / \mathrm{dm}^{3}$ do $>330 \mathrm{~g} / \mathrm{dm}^{3}$ rozpuszczonych soli, gęstości 1,2-1,29 g/ $\mathrm{cm}^{3}$ i wyjątkowo wysokiej ( $>5 \mathrm{~g} / \mathrm{dm}^{3}$ ) zawartości Br (Weiler et al. 1974; Steinhorn \& Gat R. 1982; Zak 1980, 2006). Klimat depresji jest wyjątkowo suchy, z temperaturami przy powierzchni od $20^{\circ} \mathrm{C}$ (zima) do $35^{\circ} \mathrm{C}$ (lato), roczne tempo strącania soli to $10 \mathrm{~cm}$, zaś ewaporacji $-150 \mathrm{~cm}$ (Weiler et al. 1974 - z literaturą). Morza Martwe, a szczególnie jego północna część, jest zasilane głównie przez rzekę Jordan (intensywny pobór wody z rzeki spowodował spadek poziomu solanki Morza Martwego o ponad $20 \mathrm{~m} \mathrm{w}$ ciągu ostatnich kilkunastu lat), a podrzędnie przez okoliczne powierzchniowe cieki w okresie opadów (Weiler et al. 1974). Wysoka gęstość solanek Morza Martwego utrudnia powstawanie falowania wiatrowego o większej skali - przeciętna wysokość fal to 10-20 cm, ale silne północne wiatry mogą wytworzyć fale o wysokości do 1 m (Weiler et al. 1974) i w konsekwencji - podpiętrzenia wiatrowe w strefie brzeżnej wpływające na stratyfikację solanki i powstanie w zbiorniku prądów wyrównawczych. 


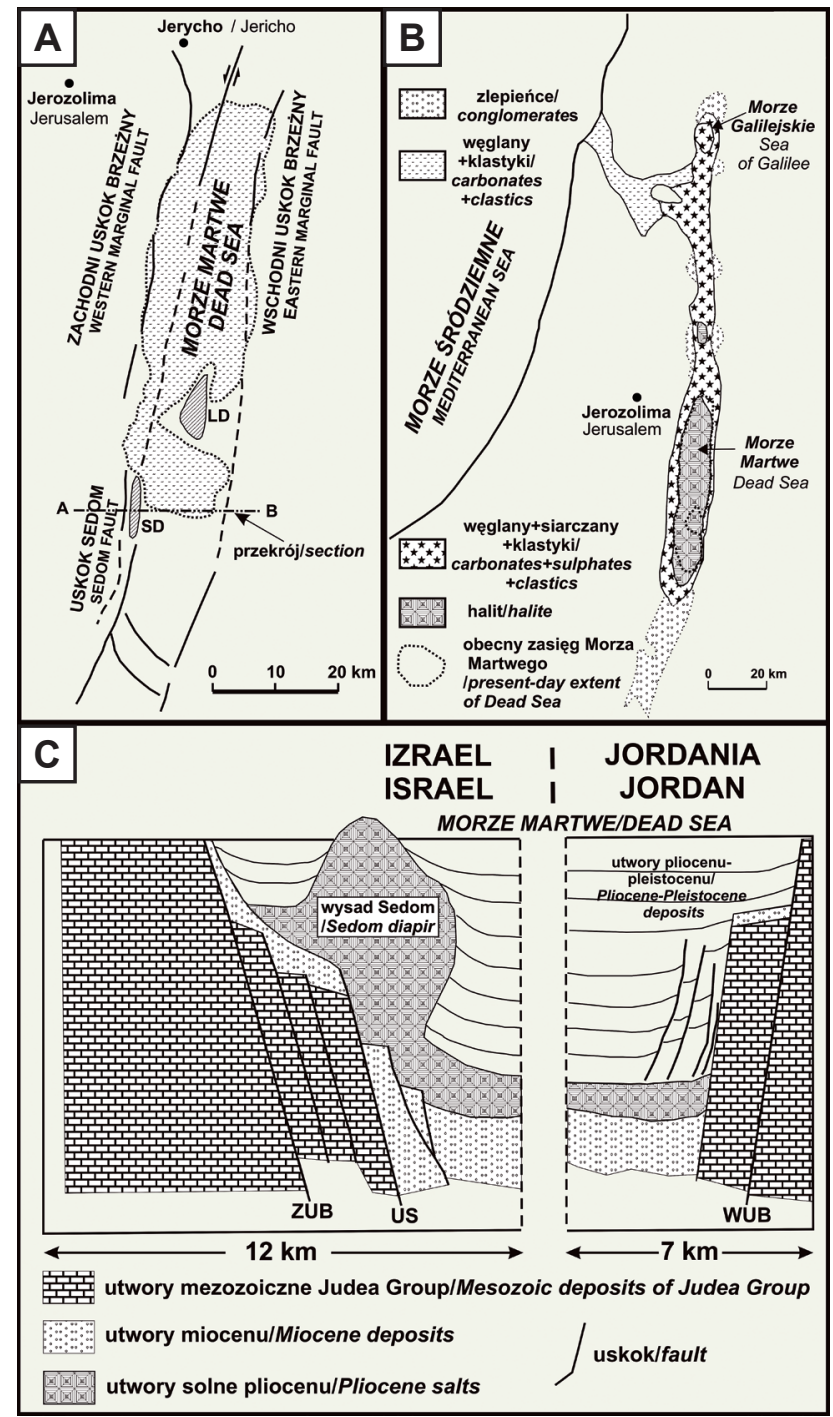

Fig. 2. Uproszczona geologia basenu Morza Martwego (wg García-Veigas et al. 2009): A) szkic tektoniczny otoczenia Morza Martwego z lokalizacją odsłonięć solnych struktur wysadowych: LD - wysad Lisan, SD - wysad Sedom; B) zasięg występowania plioceńskiej laguny Sedom z rozmieszczeniem głównych typów osadów; C) uproszczony przekrój geologiczny przez południową część basenu Morza Martwego: ZUB - zachodni uskok brzeżny, US - uskok Sedom, WUB - wschodni uskok brzeżny

Fig. 2. Simplified geology of the Dead Sea basin (after García-Veigas et al. 2009): A) tectonic sketch of the Dead Sea basin with the outcrops location of salt diapirs: LD - Lisan diapir, SD - Sedom diapir; B) extension of the Pliocene Sedom Lagoon with distribution of main facies; C) simplified cross-section from of the southern part of Dead Sea basin: ZUB - Western Border Fault, US - Sedom Fault, WUB 
W zatoce Sedom osadzają się głównie iły, aragonit i gips, zaś w okresach odcięcia zasilania wodami z części północnej - chlorki (Zak 1980). Skrajna, płytka, południowa część Zatoki została oddzielona tamą i zamieniona w system sztucznych panwi solnych, w których pozyskuje się na skalę przemysłową sól kamienną i potasową.

Z kolei plaże Morza Martwego i przyległa cześć przybrzeża to miejsce strącania halitu w formie pelitycznej, pokryw solnych, ooidów i naskorupień (Weiler et al. 1974). Falowanie, prądy i wiatr przemieszczają wytrącone kryształy halitu formując zmarszczki na dnie zbiornika (Weiler et al. 1974).

\section{JEZIORO TUZ}

Otoczony wyżynami basen słonego jeziora Tuz (typu ,playa-lake”) o powierzchni 16 tys. km² leży w środkowej Anatolii na wysokości 905 m n.p.m. i jest reliktem rozległego śródlądowego jeziora wypełniającego 23-17 tys. lat temu basen Konya (Camur \& Mutlu 1996). Basen jeziora powstał w mastrychcie, ograniczony jest uskokami o przebiegu NW-SE (Fig. 3A), zaś samo jezioro Tuz, o powierzchni $1600 \mathrm{~km}^{2}$, istnieje już od plejstocenu i zajmuje centrum basenu.

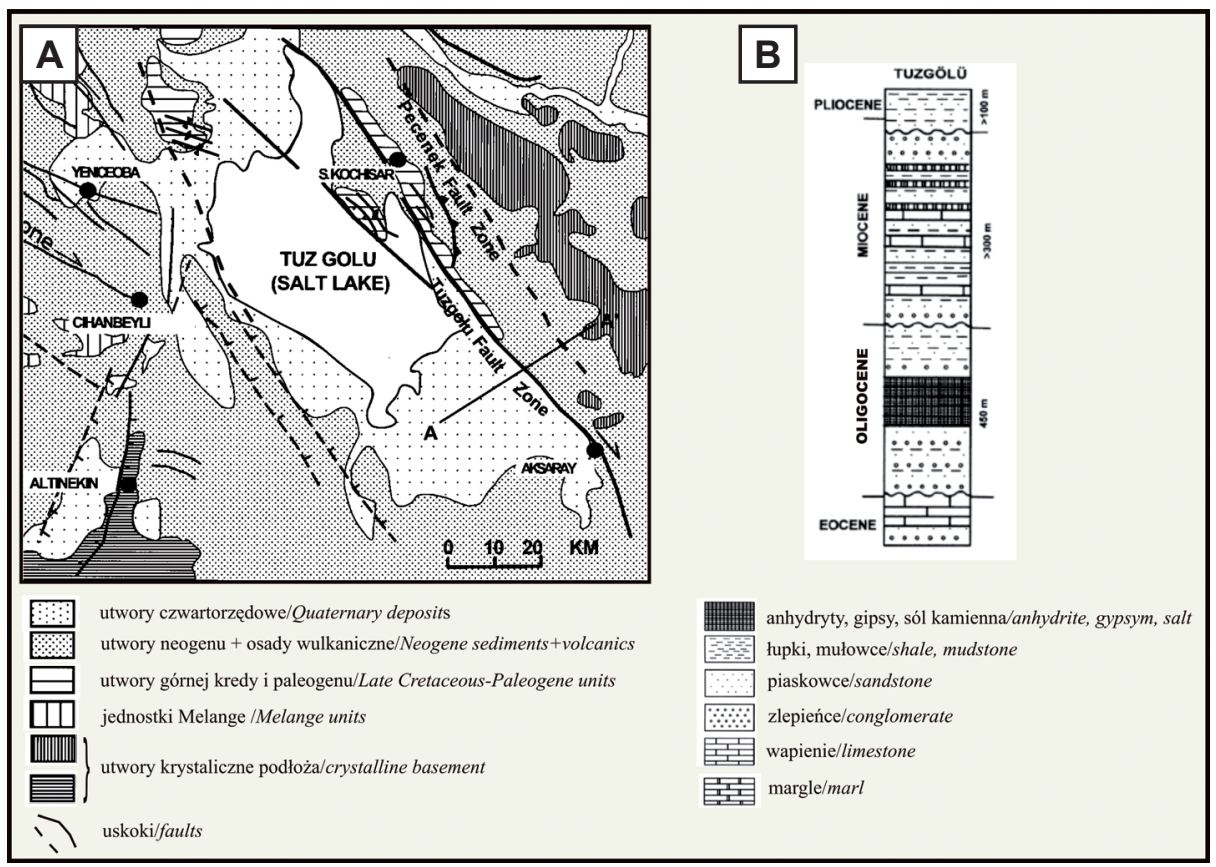

Fig. 3. Mapa geologiczna (A) okolic słonego jeziora Tuz w Turcji (wg Çemen et al. 1999) i przekrój geologiczny (B) przez osady paleogenu i neogenu w rejonie jeziora Tuz (wg Gürer \& Gürer 1999)

Fig. 3. Geological map (A) of the salt Tuz Lake environs (after Çemen et al. 1999) and the geological section (B) of the Paleogene and the Neogene sediments in the surrounding of Tuz Lake (after Gürer \& Gürer 1999) 
Podłoże basenu tworzy kompleks ofiolitowy odsłaniający się na SW i NE od jeziora (Fig. 3A), przykryty grubą pokrywą osadową wieku górna kreda-pliocen, zawierającą liczne różnowiekowe ogniwa ewaporatowe (Çemen et al. 1999, Tekin et al. 2007). Na północ od jeziora nawiercony profil osadów paleogenu-neogenu (Fig. 3B) (Gürer \& Gürer 1999) osiąga miąższość ok. $1000 \mathrm{~m}$ i składają się nań: (a) utwory eocenu (zlepieńce i piaskowce przykryte wapieniami, >100 m), (b) iłowcowo-mułowcowe, z domieszką zlepieńców i piaskowców, osady oligocenu, zawierające $>100$ m grubości kompleks ewaporatów (sole kamienne i siarczany) oraz (c) ilasto-węglanowe utwory miocenu o miąższości $>300 \mathrm{~m}$, bardziej klastyczne w dole i górze profilu, z wkładkami ewaporatów. Całość przykrywa iłowcowo-piaszczysta seria plioceńska grubości $>100 \mathrm{~m}$. Osady poszczególnych serii oddzielają powierzchnie erozji. Badania geofizyczne prowadzone w rejonie jeziora Tuz w ramach poszukiwań złóż ropy naftowej wykazały występowanie w podłożu basenu szeregu wysadów solnych różnych rozmiarów (Yildiz \& Soğanci 2010).

Współczesne osady w basenie to głównie gipsy i dolomity z magnezytem, huntytem i polihalitem (Kilic \& Kilic 2010).

Jezioro jest podzielone barierą na dwie części: większa, zachodnia jest płytsza (do 0,7 m) i latem wysycha, wschodnia jest głębsza (ok. $1 \mathrm{~m}$ ) i przez cały rok zalana. W okresie suchym sól wytrąca się na obszarze ok. $1200 \mathrm{~km}^{2}$ (Fig. 4E), tworząc ciągły pokład halitowy o grubości do $30 \mathrm{~cm}$.

W świetle najnowszych danych współczesny mechanizm formowania soli w jeziorze jest wiązany z utworami solnymi występującymi w podłożu basenu i wokół jeziora. Występujące w podłożu osady solne starszych ogniw są częściowo rozpuszczane przez wody podziemne migrujące wzdłuż stref uskokowych, a powstałe roztwory po przetransportowaniu do basenu jeziora ulegają ewaporacji (Yildiz \& Soğanci 2010).

Solanki jeziora Tuz wykazują zmienność między typem $\mathrm{Na}-\mathrm{K}-\mathrm{Mg}-\mathrm{Ca}-\mathrm{Cl}$ a typem Na-K-Mg-Cl-SO4 i można je określić jako solanki typu Na-Cl (Kilic \& Kilic 2005).

\section{CHARAKTERYSTYKA KULISTYCH FORM AKUMULACJI HALITOWEJ (Fig. 4)}

Kuliste i owalne twory solne o średnicy 0,8-4,0 mm opisano (Weiler et al. 1974) jako ooidy halitowe (,halolites”). Mają one zwykle budowę powłokową, podkreśloną rozmieszczeniem inkluzji stałych, rzadziej budowę promienistą, jądro stanowi najczęściej kryształ halitu, rzadziej okruch skalny. Powierzchnia ooidów jest gładka, budują je kryształy halitu, niekiedy jest to jeden duży kryształ soli (Weiler et al. 1974). Twory te napotkano na stosunkowo nisko położonej $(0,2-0,5 \mathrm{~m}$ ponad poziom solanki) i wąskiej terasie brzegowej, gdzie budowały niewielkie odsypy (bermy) dzięki sporadycznym wezbraniom sztormowym. Mechanizm ich powstania jest podobny jak ooidów węglanowych (Weiler et al. 1974): we wzburzonej silnym falowaniem wiatrowym (sztorm) solance w strefie przybrzeża następował szybki przyrost ,powłok” halitowych wokół zawieszonych kryształów halitu czy okruchów skalnych. Duża gęstość i lepkość solanki sprzyjały formowaniu ooidów większych rozmiarów niż klasyczne struktury węglanowe. Zawieszone w solance ooidy były następnie wynoszone na plażę podczas maksymalnego zasięgu falowania, gromadząc się tam w formie bermu niszczonego później przez wody opadowe (Weiler et al. 1974). 

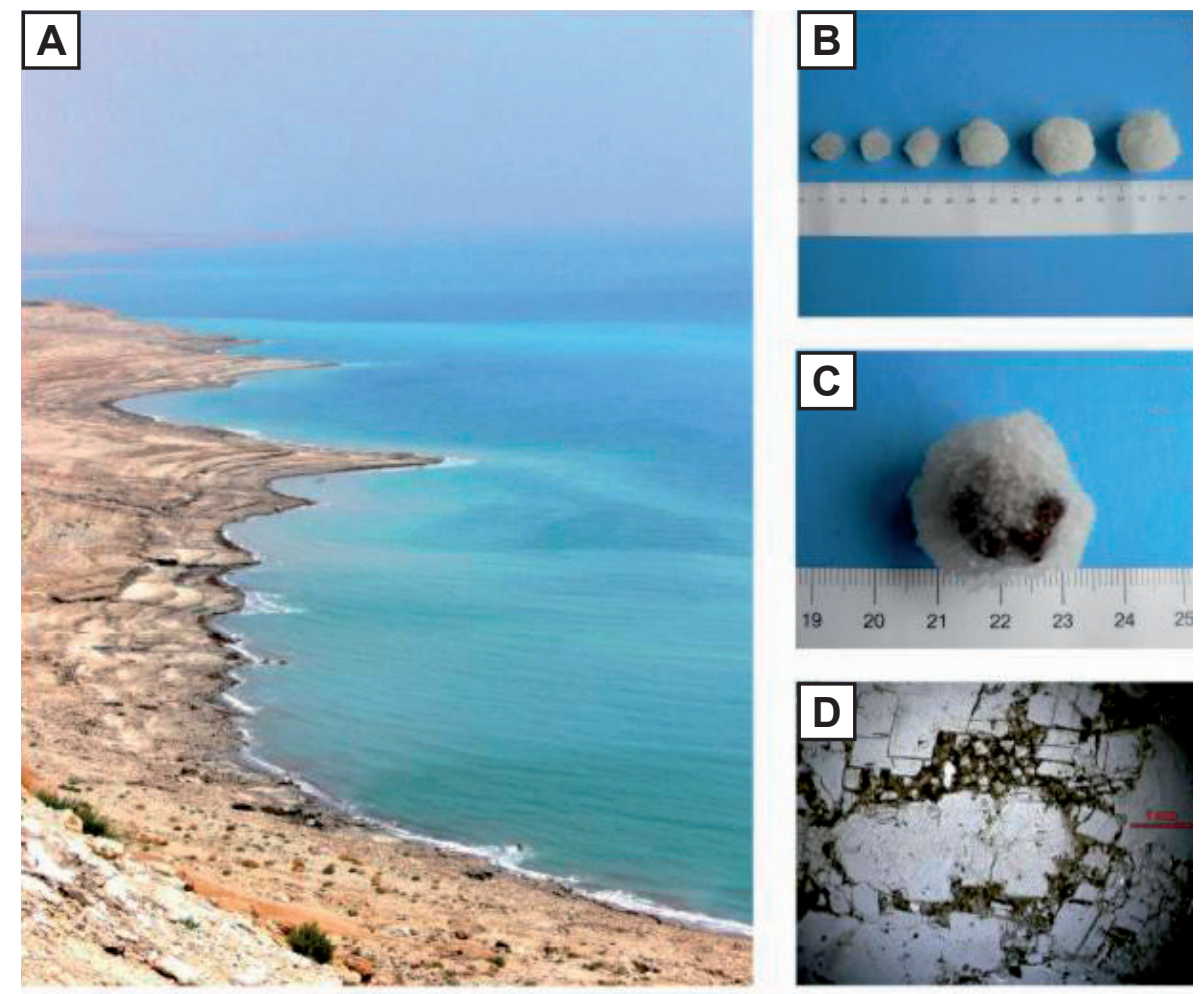

E
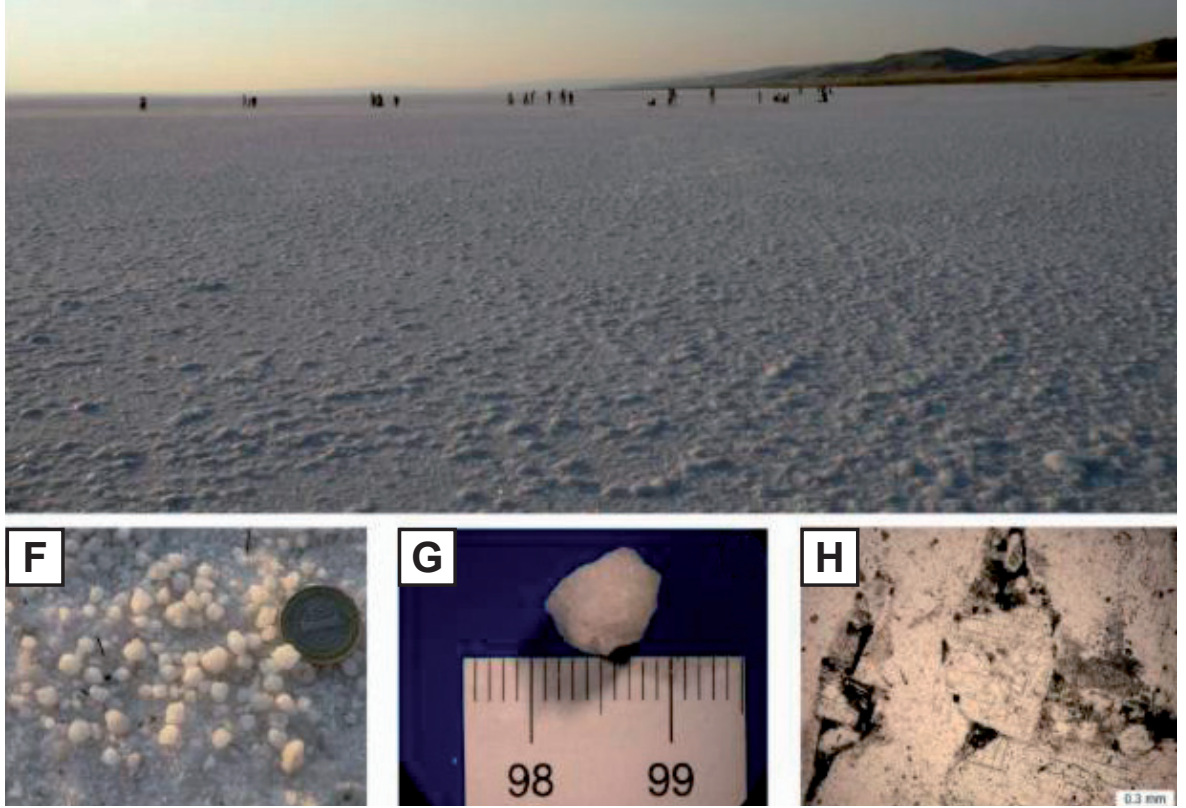

Fig. 4. Opisywane formy solne z wybrzeża Morza Martwego (A-D) i z jeziora Tuz (E-H): A) wybrzeże Morza Martwego ze strefami płycizn (jaśniejsze partie akwenu); B) kuliste agregaty halitowe z okolic kąpieliska Newe Zohar nad Morzem Martwym; C) okruch skalny „obrośnięty” kryształkami halitu (Morze Martwe); D) obraz mikroskopowy wewnętrznej budowy kulistego agregatu halitowego z Morza Martwego; E) pokrywa solna jeziora Tuz w porze suchej (część wschodnia); F) kuliste agregaty halitowe na wyschniętej powierzchni jeziora Tuz; G) ,przeciętny” okaz agregatu halitowego z terenu jeziora Tuz; H) obraz mikroskopowy wewnętrznej budowy agregatu halitowego z jeziora Tuz

Fig. 4. Described salt structures from the Dead Sea shore (A-D) and the Tuz Lake (E-H): A) Dead Sea coast with nearshore shoals (light zones in the basin); B) spherical halite aggregates from the near shore zone at Newe Zohar (Dead Sea); C) rocky nucleus covered with halite crystals (Dead Sea); D) photomicrograph of the internal structure of the halite spherical aggregate from the Dead Sea; E) halite surface crust in the eastern part of Tuz Lake during dry season; F) spherical aggregates of halite crystals on the dried surface of the Tuz Lake; G) size of average halite aggregate form the Tuz Lake; H) photomicrograph of the internal structure of the halite aggregate from the Tuz Lake 
Sferyczne i owalne „kulki” solne, napotkane w Morzu Martwym na dnie kąpieliska koło Newe Zohar (na głębokości 1,0-2,5 m) w strefie, gdzie zaobserwowano wyraźne prądy w solankach (Burliga et al. 2007), różnią się od opisywanych dotychczas ooidów solnych. Usiane jest nimi dno płytkiego przybrzeża (zebrano ponad 300 okazów), a nie plaża, „kulki” mają różną wielkość - ich średnica wynosi od kilku milimetrów do kilku centymetrów (Fig. 4B). Jądro niektórych większych „kulek” stanowi okruch skalny (Fig. 4C). Obserwacje mikroskopowe nie wykazały warstwowej, koncentrycznej budowy wewnętrznej form, stanowią one raczej mniej lub bardziej sferyczny zlepek kryształków halitu o średnicy: 0,5-3,0 mm (Fig. 4D). Ich powierzchnia rzadko jest gładka, zwykle jest nierówna, widoczne są mniejsze i większe kryształy halitu (Fig. 4C), tworzące zewnętrzną część agregatu solnego. Ze względu na wielkość, przekraczającą znacznie średnice opisywanych dotychczas (Weiler et al. 1974) ooidów halitowych, omawiane formy należałoby nazwać ,pizoooidami halitowymi”.

Twory solne o podobnym kształcie napotkano na powierzchni pokrywy solnej w strefie przybrzeżnej jeziora Tuz (strona wschodnia głównej strefy jeziora - Fig. 4E), utworzonej w wyniku odparowania wód jeziora w okresie letnim. „Kulki” solne z jeziora Tuz są mniej zróżnicowane pod względem wymiarów (Fig. 4F), ich średnica zazwyczaj nie przekracza 5-7 mm (Fig. 4G). Badania mikroskopowe wykazały, że formy te także stanowią agregaty małych kryształków halitu (Fig. 4H). Agregaty te są zwykle dość kanciaste, ich powierzchnie są czasem lekko wygładzone, krawędzie zewnętrznych kryształków halitu i ich naroża - zaoblone. Szereg form to po prostu duże pojedyncze kryształy halitu o zaoblonych narożach. Omawiane twory przypominają kształtem opisane z kanałów rozprowadzających solankę w jeziorze Tuz ooidy halitowe (Tekin et al. 2007).

Zawartość bromu oznaczono w trzech okazach ,kulek” solnych (jeden okaz z Morza Martwego i dwa z jeziora Tuz) oraz w próbce plioceńskiej soli kamiennej z formacji Sedom, pobranej z odsłaniającego się na powierzchni wysadu Sedom nad Morzem Martwym (Tab.1). Próbkę z Morza Martwego oraz z wysadu Sedom poddano pełnej analizie chemicznej metodą ICP-OES (za pomocą urządzenia Spectro CIROS) w laboratorium BGR w Hanowerze. W „kulkach” z jeziora Tuz oznaczono zawartość bromu metodą XRF (przy użyciu spektrometru fluorescencji rentgenowskiej model PW 2400 firmy Philips) w Centralnym Laboratorium Chemicznym PIG-PIB. Oznaczone zawartości są wysokie (174-504 ppm), zbliżone do zawartości spotykanych w halitach powstałych z morskich solanek. Najwyższą zawartością bromu charakteryzuje się okaz z Morza Martwego. Obliczony skład mineralny wykazał, że próbka ta składa się głównie z halitu, a więc brom związany jest przede wszystkim z tym minerałem (Tab. 1). Wysoka zawartość bromu (499 ppm) jest wynikiem bardzo wysokiej koncentracji współczesnych solanek (które wyewoluowały z pierwotnych wód morza plioceńskiego - Zak 2006) w zbiorniku bezodpływowym w warunkach suchego gorącego klimatu $\mathrm{z}$ niewielkimi opadami i wysokim tempem ewaporacji.

W chlorkowych produktach ewaporacji powstałych w środowisku śródlądowych zbiorników jeziornych niejednokrotnie obserwowana jest wysoka zawartość bromu 
zbliżona do typowej dla ewaporatów ze zbiorników zasilanych wodą morską (Hardie 1984). Wzbogacenie w brom solanek zbiornika śródlądowego, niewywodzących się z solanek morskich, może nastąpić m.in. w wyniku: (1) ługowania starszych chlorkowych soli potasowych (sylwinu, karnalitu) występujących w podłożu bądź w bliskim sąsiedztwie, (2) dopływu do zbiornika macierzystych solanek starszych utworów solnych, (3) dopływu do zbiornika wód z gorących źródeł wulkanogenicznych oraz (4) docierania do zbiornika aerozoli soli morskich rozpuszczonych w wodzie deszczowej (Hardie 1984). Przy interpretacji kopalnych utworów solnych należy zatem z dużą ostrożnością sugerować się zawartością bromu w solach chlorkowych jako decydującym wskaźnikiem ich powstania w zbiorniku morskim.

\section{Tabela (Table) 1}

Zawartość bromu w agregatach halitowych (HA) z Morza Martwego (Izrael) i z jeziora Tuz (Turcja) oraz w próbce soli kamiennej (RS) z wysadu Sedom (Izrael)

Bromine content in the halite aggregates (HA) from the Dead Sea (Israel) and from the Tuz Lake

(Turkey) and in the halite sample (RS) from the Sedom diapir (Israel)

\begin{tabular}{|c|c|c|}
\hline $\begin{array}{c}\text { Miejsce poboru i rodzaj próbki } \\
\text { Type \& sampling site }\end{array}$ & $\begin{array}{c}\text { Zawartość bromu } \\
\text { Bromine content } \\
{[\mathrm{ppm}]}\end{array}$ & $\begin{array}{c}\text { Zawartość bromu w halicie } \\
\text { Bromine content in halite } \\
{[\mathrm{ppm}]}\end{array}$ \\
\hline $\begin{array}{c}\text { Morze Martwe (HA) } \\
\text { Dead Sea }\end{array}$ & 504 & 499 \\
\hline $\begin{array}{c}\text { Wysad Sedom (RS) } \\
\text { Sedom diapir }\end{array}$ & 121 & - \\
\hline $\begin{array}{c}\text { Jezioro Tuz (HA) } \\
\text { Tuz Lake }\end{array}$ & 174 & - \\
\hline $\begin{array}{c}\text { Jezioro Tuz (HA) } \\
\text { Tuz Lake }\end{array}$ & 211 & - \\
\hline
\end{tabular}

\section{GENEZA KULISTYCH FORM SOLNYCH}

Jak wcześniej wspomniano, zbadane twory solne przypominają opisywane ooidy halitowe kształtem, jednak są zwykle większe (np. formy z Morza Martwego) i mają odmienną strukturę wewnętrzną. Brak koncentrycznej budowy nie powala ich sklasyfikować jako ooidy.

Formy z dna Morza Martwego to pizooidy, które powstały w strefie płytkiego przybrzeża wskutek dalszego narastania kryształów halitu na pierwotnych ooidach halitowych. Przydenne prądy wyrównawcze, wynikające z różnic gęstości solanki (cięższa, bardziej skoncentrowana przy brzegu solanka odpływa po skłonie przybrzeża w głąb zbiornika) oraz prądy 
wywołane falowaniem sztormowym przemieszczały nad dnem i po dnie coraz większe i cięższe agregaty solne. Duża lepkość solanki utrudniała wzajemne ścieranie się agregatów (Weiler et al. 1974), pozwalając im zachować nierówne powierzchnie, bez śladów zniszczeń tworzących je kryształków halitu. Formy te nigdy nie zostały wyrzucone na brzeg tak jak udokumentowane dotychczas ooidy halitowe (Weiler et al. 1974) i pozostają stale w strefie przybrzeża, miejscu ich narodzin.

Inaczej powstały sferyczne twory pobrane z jeziora Tuz. Obok agregatów kryształów halitu występują tu jego pojedyncze większe kryształy, charakteryzuje je lepszy lub gorszy stopień wygładzenia naroży i krawędzi. Formy te są prawdopodobnie oderwanymi przez wiatr fragmentami i pojedynczymi kryształami jeszcze nieskonsolidowanej, odsłoniętej skorupy solnej. Toczone po nierównej powierzchni skorupy (Fig. 4F), agregaty i większe kryształy były częściowo kruszone i ścierane, co skutkowało nadaniem im w mniejszym lub większym stopniu formy sferycznej. Przesuwane przez wiatry wiejące nad otwartym akwenem jeziora Tuz z dużą siłą, „kulki” gromadzą się w nierównościach skorupy solnej i tuż przy krawędzi plaży. Ze względu na mechanizm powstania można je uznać za „ooidy eoliczne”, choć nie są produktem agradacji mineralnej w dynamicznym środowisku subakwalnym, a jedynie mechanicznej obróbki przez wiatr okruchów osadu.

\section{PODSUMOWANIE}

Charakterystyka specyficznych sferycznych i owalnych form akumulacji halitu (tzw. „kulki” solne) i miejsc ich pobrania (Morze Martwe w Izraelu i jezioro Tuz w Turcji) wskazuje, że pomimo podobieństw kształtu i budowy wewnętrznej są to twory o odmiennej genezie.

Formy z Morza Martwego to pizooidy halitowe powstałe na bazie opisywanych już wcześniej z tego zbiornika ooidów halitowych. Powstały w wyniku dalszej agradacji kryształów halitu na inicjalnych ooidach w środowisku płytkiego przybrzeża, cechującego się obecnością stałych przydennych prądów (gęstościowe prądy wyrównawcze) i okresową silną dynamiką (falowanie sztormowe).

Sferyczne formy z jeziora Tuz to swoiste „ooidy eoliczne”, produkt mechanicznej obróbki przez wiatr okruchów osadu (agregaty i pojedyncze kryształy halitu), oderwanych z nieskonsolidowanej, odsłoniętej skorupy solnej i przetaczanych po jej powierzchni.

\section{LITERATURA}

Burliga S., Czapowski G., Bukowski K., Tomassi-Morawiec H. \& Wachowiak J., 2007. Morze Martwe 2006. Wyprawa naukowa Polskiego Stowarzyszenia Górnictwa Solnego 27 maja - 4 czerwca. Gospodarka Surowcami Mineralnymi [Przeglad Solny], 23, 1, 215-224. 
Camur M.Z. \& Mutlu H., 1996. Major-ion geochemistry and mineralogy of the Salt Lake (Tuz Gölü) basin, Turkey. Chemical Geology, 127, 4, 313-329.

Castanier S., Perthuisot J.-P., Rouchy J.-M., Maurin A. \& Guelorget O., 1992. Halite ooids in lake Asal, Djibouti: biocrystalline build-ups. Geobios, 25/6, 811-821.

Castanier S., Perthuisot J.-P., Matrat M. \& Morvan J.-Y, 1999. The salt ooids of Berre salt works (Bouches du Rhône, France): The role of bacteria in salt crystallization. Sedimentary Geology, 125, 1-2, 9-21.

Çemen I., Göncüoglu M.C., Dirik K., 1999. Structural Evolution of the Tuzgölü Basin in Central Anatolia, Turkey. The Journal of Geology, 107, 693-706.

García-Veigas J., Rosell L., Zak I., Playà E., Ayora C. \& Strainsky A., 2009. Evidence of potash salt formation in the Pliocene Sedom Lagoon (Dead Sea Rift, Israel). Chemical Geology, 265, 3-4, 499-511.

Gürer Ö.F., Gürer A., 1999. Development of Evaporites and the Counterclockwise Rotation of Anatolia, Turkey. International Geology Review, 41, 607-622.

Hardie L.A., 1984. Evaporites: marine or non-marine? American Journal of Science, 284, 3, $193-240$.

Kilic O. \& Kilic A.M., 2005. Recovery of salt co-products during the salt production from brine. Desalination, 186, 11-19.

Kilic O. \& Kilic A.M., 2010. Salt crust mineralogy and geochemical evolution of the Salt Lake (Tuz Gölü), Turkey. Scientific Research and Essays, 5, 11, 1317-1324.

Melvin J.L., 1991. Evaporites, Petroleum and Mineral Resources. Developments in Sedimentology, 50, 1-556.

Raab M., Friedman G.M., Spiro B., Starinsky A. \& Zak I., 2000. The geological history of Pliocene-Pleistocene evaporites in Mount Sedom (Israel) and how strontium and sulfur isotopes relate to their origin. Carbonates and Evaporites, 15, 2, 93-114.

Rosenthal E., Flexer A. \& Möller P., 2006. The paleoenvironment and the evolution of brines in the Jordan-Dead Sea transform and in adjoining areas. Journal of Earth Sciences, 95, 4, 725-740.

Schreiber B.C. \& El Tabakh M., 2000. Deposition and early alternation of evaporites. Sedimentology, 47, 1, 215-238.

Sonnenfeld P., 1984. Brines and evaporates. Academic Press, London.

Steinhorn I. \& Gat J.R., 1982. The Dead Sea. Scientific American, 249, 102-109.

Tekin E., Ayyildiz T., Gündoğan İ. \& Orti F., 2007. Modern halolites (halite oolites) in the Tuz Gölü, Turkey. Sedimentary Geology, 195, 3-4, 101-112.

Warren J.K., 2006. Evaporites: Sediments, Resources and Hydrocarbons. Springer-Verlag, Berlin Heidelberg.

Weiler Y., Sass E. \& Zak I., 1974. Halite oolites and ripples in the Dead Sea. Sedimentology, $21,4,623-632$. 
Weinberger R., Begin Z.B., Waldmann N., Gardosh M., Baer G., Frumkin A. \& Wdowinski S., 2006. Quaternary rise of Sedom Diapir, Dead Sea Basin. Geological Society of America Special Publication, New Frontiers in Dead Sea Paleoenvironmental Research, Geological Society of America Special Paper, 401, 33-51.

Yildiz M. \& Soğanci A.S., 2010. Evaluation of geotechnical properties of the salt layers on the Lake Tuz. Scientific Research and Essays, 5, 18, 2656-2663.

Zak I., 1967. The geology of Mount Sedom. Hebrew University, Jerusalem [rozprawa doktorska, niepubl., angielski abstrakt].

Zak I., 1980. The Geochemical Evolution of the Dead Sea. $5^{\text {th }}$ Symposium on Salt, the North. Ohio Geological Society, 1, 181-184.

Zak I., 2006. Evolution of the Dead Sea brines. Abstracts of RCMNS Interim Colloquium, 7-9 September, Parma, Italy, Acta Naturalia de “L'Ateneo Parmense”, 42, 2, A61 SS2. 